Original Article

\title{
The Upper Juruá Extractive Reserve in the Brazilian Amazon: past and present ${ }^{1}$
}

\author{
A Reserva Extrativista do Alto Juruá na Amazônia Brasileira: passado e presente
}

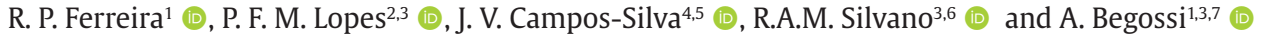 \\ ${ }^{1}$ Graduate Program/Universidade Santa Cecília, Santos, SP, Brasil. \\ ${ }^{2}$ Universidade Federal do Rio Grande do Norte, Departamento de Ecologia, Fisheries management, Ecology and Economics Group, Natal, RN, Brasil. \\ ${ }^{3}$ Fisheries and Food Institute - FIFO, Rio de Janeiro, RJ, Brasil. \\ ${ }^{4}$ Norwegian University of Life Sciences, Faculty of Environmental Sciences and Natural Resource Management, Ås, Norway. \\ ${ }^{5}$ Universidade Federal de Alagoas, Instituto de Ciências Biológicas e da Saúde, Maceió, AL, Brasil Maceió, AL, Brasil. \\ ${ }^{6}$ Universidade Federal do Rio Grande do Sul - UFRGS, Departamento de Ecologia e Programa de Pós-graduação em Ecologia - IB, Rio Grande do Sul, Brasil. \\ ${ }^{7}$ Universidade Estadual de Campinas - UNICAMP, Programa de Capacitação de Pescadores - CAPESCA, Núcleo de Estudos e Pesquisas em \\ Alimentação - NEPA, Campinas, SP, Brasil.
}

${ }^{1}$ In memory of Benedito D. Amaral

\begin{abstract}
Amazonian livelihoods are largely dependent on rivers, with local protein consumption mainly relying on several species of fish. The UJER (Upper Juruá Extractive Reserve - Reserva Extrativista do Alto Juruá) is located in the state of Acre, bordering Peru and several indigenous areas. Here we summarize the data we collected in 1993/1994 on the population living along the banks of the Juruá, Tejo, Bagé, Igarapé São João and Breu rivers on crop cultivation, animal husbandry, and use of game and fish resources. We interviewed 133 individuals (94 on the Juruá and Tejo, 16 on Bagé, 16 on Igarapé São João and 7 on Breu rivers). Our results include a comprehensive description on local livelihoods, including the most important fish species for local subsistence considering gender and seasonality, the main husbandry and game species, and the items cultivated on the local agriculture. Whenever more recent information was available in the literature, we compared changes in livelihoods over time in the same region and also with the recent patterns observed in the Lower and in the Middle Juruá River. We hope to provide useful information to understand temporal changes in local livelihoods, which can help adapt and shape the ecological management in the region.
\end{abstract}

Keywords: biodiversity, extractive reserves, fish, food security, Upper Juruá, Livelihoods, RESEX.

\begin{abstract}
Resumo
Comunidades da Amazônia são amplamente dependentes dos rios, com o consumo local de alimentos baseado em várias espécies de peixes. A UJER (Reserva Extrativista do Alto Juruá - Reserva Extrativista do Alto Juruá) está localizada no estado do Acre, na fronteira com o Peru e com várias áreas indígenas. Aqui resumimos os dados que coletamos em 1993/1994 da população que vive às margens dos rios Juruá, Tejo, Bagé, Igarapé São João e Breu sobre cultivo, criação de animais e uso de recursos de caça e peixes. Foram entrevistados 133 indivíduos (94 nos rios Juruá e Tejo, 16 em Bagé, 16 em Igarapé São João e 7 no rio Breu). Nossos resultados incluem uma descrição abrangente dos meios de subsistência locais, incluindo as espécies de peixes mais importantes para a subsistência local, considerando gênero e sazonalidade, bem como as principais espécies de criação, de caça e os itens cultivados na agricultura local., Quando foi possível obter informações da literatura, comparamos as mudanças nos meios de subsistência ao longo do tempo na mesma região e também com os padrões recentes observados no Baixo e no Médio Rio Juruá. Esperamos fornecer informações úteis para o entendimento das mudanças temporais nos meios de subsistência locais, o que pode ser útil ao manejo ecológico da região.
\end{abstract}

Palavras-chave: biodiversidade, reservas extrativistas, peixes, segurança alimentar, Alto Juruá, modos de vida, RESEX.

\section{Introduction}

As the pressures mount over Amazonia, the region is at a crossroads regarding biodiversity conservation and livelihoods of local people, which tend to be largely

dependent on rivers (Begossi et al., 2019). Adding to that, most of the local conservation initiatives do not properly include aquatic ecosystems (Castello et al., 2013), while

* priscila@cb.ufrn.br; albegossi@gmail.com

Received: 05 June 2020 - Accepted: 01 Sep. 2020

This is an Open Access article distributed under the terms of the Creative Commons Attribution License, which permits unrestricted use, distribution, and reproduction in any medium, provided the original work is properly cited. 
the ones that do struggle against governmental pressures that try to downgrade, downsize and degazette them (Ferreira et al., 2014). Also, protected and unprotected areas suffer from various impacts, including the establishment and planning of hundreds of hydroelectric dams (Winemiller et al., 2016), new roads and the increasing deforestation rates for cattle pastures and soybean crops, which now form large corridors isolating fragments of forest (Fearnside, 2001, 2007, 2017a, b). All of these changes have consequences on terrestrial and aquatic environments. Large dams for hydropower generation, for example, have affected fish and fisheries in large Amazonian rivers, by reducing the availability of commercial migratory fish, extinguishing fish species that depend on specific habitats flooded by dams, and changing fish community by transforming lotic environments into lentic ones (Petrere, 1996; Hallwass et al., 2013a; Santos et al., 2018, 2020; Arantes et al., 2019).

An alternative to slow down the negative pressures on the Amazonia is the establishment of reserves or agreements between the local people and the government, such as participatory regimes to regulate the use of resources, including co-management strategies (Lopes et al., 2011). Co-management systems of fishing resources are locally based and can include the active participation of fishers with the support of government, civil society and research institutions (Castilla and Defeo, 2001; Gutierrez et al., 2011). In the last decades, several locally based and bottom-up co-management systems emerged in the Brazilian Amazon with the goal of managing fishing territories (usually floodplain lakes), by excluding outsiders that do not follow management rules, such as fishing restrictions or no-take areas (Begossi et al., 1999; Castro and McGrath, 2003; Lopes et al., 2011; Campos-Silva and Peres, 2016). Co-management has shown great potential to improve fishing yields and increase fish abundance in the more productive white water floodplains (Almeida et al., 2009; Castello et al., 2009; Silvano et al., 2009; Campos-Silva and Peres, 2016). Although less studied, there is evidence that co-management also contributes to increased fishing yields, fish abundance or reduced fishing pressure in the less productive clear and black water rivers in the Brazilian Amazon (Sobreiro et al., 2010; Silvano et al., 2014, Keppeler et al., 2017).

Besides the increase in fishing yields, co-management has also the potential to catalyze social transformations of disenfranchised rural communities. Income generation for instance can improve the livelihoods, not only at a family level, but also at a community level, improving common infrastructure (Campos-Silva and Peres, 2016; Freitas et al., 2020a, b). Co-management can also ensure important non-monetary values, including cultural maintenance and increasing of community self-esteem (Campos-Silva and Peres, 2016). Finally, co-management can also help with the global fight against gender inequality, generating a rare economic opportunity for women (Freitas et al., 2020a, b).

Co-management systems can be established either in or outside reserves. The Brazilian National System of Protected Areas (SNUC, acronym in Portuguese) includes some categories of protected areas that are exclusively based on co-management arrangements. One of these categories are the Extractive Reserves, which have as their main goals the protection of biodiversity associated to the maintenance of sustainable economic activities by local people, usually with a strong focus on fishing resources (Lopes et al., 2011). The Upper Juruá Extractive Reserve (hereafter UJER), in Portuguese Reserva Extrativista do Alto Juruá, was created in 1990, representing the first of its type established in Brazil, located in the State of Acre, in the Brazilian Amazon. Its creation had the participation of rubber-tapper associations and grassroots movements: their pressure towards the governmental environmental agencies resulted in increasing the extension of the reserve, by including, besides the major Juruá river, the Tejo river (Almeida, 2004).

Several co-management initiatives focus on fish due to its relevance for Amazonian food security, although there is relatively high variation in fish intake per capita, ranging from an average of $87 \mathrm{~g}$ of fish per day (Isaac et al, 2015) to $805 \mathrm{~g}$ (Begossi et al., 2019; Issac and Almeida, 2011). Regardless of such variations, fish is an important protein source and its extraction through fishing, by riverine people, represents a positive cost-benefit ratio compared to other sources of meat, especially those acquired in external markets (Silva and Begossi, 2009). For example, studies about riverine people at the Mekong River, specifically in Cambodia and Laos, show that shifting protein based on aquatic resources to land resources produce impacts on land uses, water consumption, and nutritional value of the protein (Orr et al., 2012). Forests provide food for native people; fishing, in particular, is among the most important economic activity in Amazonian rivers for providing food and for being a source of income, where formal jobs are almost non-existent (Pimentel et al., 1997; MacCord et al., 2007; Hallwass et al., 2011, 2013b; Hallwass and Silvano, 2016).

Much of what is known about the UJER is found in the grey literature, such as dissertations on the relations of patronage (definitions about these relations in Brazil are found in Carvalho, 1997), and other archaic rural forms and obstacles to local movements that sometimes ended in local conflicts (Lozano, 1998, 2010), on the effects of government interventions and programs at UJER (Freitas, 2012), or on the effects of local collective rights within the UJER (Luna, 2014). Archaic patronage systems were still in place in 1993, representing an important obstacle for the trades of goods produced or needed by the ribeirinhos.

After 30 years of creation of an extractive reserve at the Upper Juruá river, not much is known about how the riverine population has used the local natural resources, in spite of UJER original goal of reconciling conservation with the promotion of sustainable livelihoods. There is also very little information in the literature on how this use has possibly changed over time. We summarize here the data we collected in 1993 and 1994 (partially published by Begossi et al., 1999) concerning the use of game and fish resources by men and women and according to seasonal variations. By also providing comparative figures among different decades (whenever possible according to the literature available), we hope to provide guided information for the management of food resources. 


\section{Methods}

\subsection{Study area}

The UJER, created by Decree \#98,863 of January 23, 1990, covers 537,946.47 hectares (www.icmbio.gov.br). According to the Instituto Chico Mendes de Conservação da Biodiversidade (ICMBio), Ministry of the Environment, the UJER still has no management plan. The RESEX includes the towns of Jordão, Marechal Thaumaturgo, Porto Walter and Tarauacá. The UJER reaches the border of Peru (through the Breu river) and it also borders the indigenous territories of the Kampa, Jaminawa-Arara, and Kaximinaua tribes. About 7,500 people live within the limits of the reserve, who descend mostly from rubber tappers. Rubber tappers first arrived in the region in the 1890 s, coming from contested areas of Peru and Bolivia. A second migration occurred in the forties, during World War II, when rubber tappers were recruited by the Brazilian government, especially among the northeastern population, who were nicknamed the Rubber Soldiers (Soldados da Borracha or Batalha da Borracha) (Almeida, 2004; Almeida and Menezes, 1994; Brasil, 2009).
The main river crossing the reserve is the Juruá, a white water river with a low slope (Brasil, 2009). The Juruá river rises in Peru at an altitude of approximately $450 \mathrm{~m}$ and has a length of $3,280 \mathrm{~km}$; it crosses the States of Acre and Amazonas, discharging waters in the Solimões River (Costa et al., 2012). Tributaries of the right margin of the Juruá river are the rivers Breu, Caipora, São João, Acuriá, Tejo, Grajaú, Natal, Humaitá and Valparaíso. Juruá is a navigable river including for large vessels between the municipality of Cruzeiro do Sul and Marechal Thaumaturgo (Upper Juruá) (Costa et al, 2012). As a white water river in Amazonia, the Juruá River forms the areas of várzea (lowland flooded forests), which are mosaic of habitats subject to seasonal flooding, that have a very high biodiversity (Goulding et al., 2003). The rainy season (winter, September to March) corresponds to the flooding period, whereas the dry season (summer, April to August) is marked by low water levels (Costa et al., 2012). In 1993 and 1994, we interviewed riverine inhabitants of the banks of important UJER rivers: Juruá and Tejo (here considered together), Bagé, São João, and Breu (Figures 1a, b).

The ribeirinhos (riverine people living along the river banks) studied at the UJER live in houses located by white
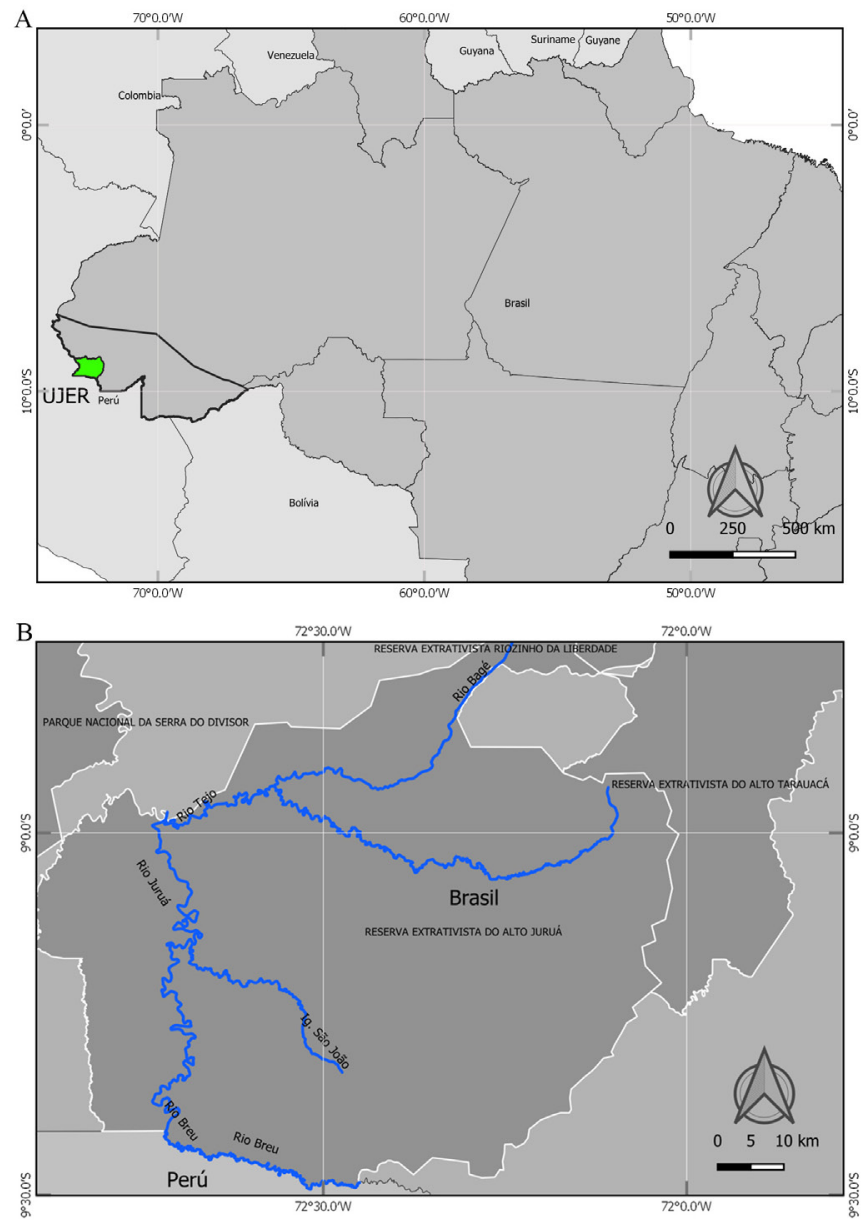

Figure 1. Map of the Upper Juruá Extractive Reserve: a) its location in Brazil, Acre State; b) some of the rivers that flow within the reserve that had their riverine populations studied here. 
water rivers, allowing fishing to be performed by the whole family, including children, which probably decreases the chance of food insecurity, due to available protein. The UJER has defined rules that allow local residents to exclude outsiders and invaders unable to abide by the restrictive harvesting rules. The access control to restrictive fishing areas was aided by a simple, but powerful radio communication system (Radio ‘Verdes Florestas' - Green forests) (Almeida and Menezes 1994; Begossi, 2001; Begossi and Brown, 2003).

\subsection{Data collection}

The data presented here were partially published (especially data on game and fish) by Begossi et al., (1999). All the information was collected through interviews, using open and semi-structured standardized questions, conducted in July 1993 and July 1994, by A. Begossi and BD Amaral., The questionnaires are deposited at FIFO (Fisheries and Food Institute, www.fisheriesandfood. com) under the number PAJUR 007 and the project was funded by Fapesp 98 / 02619-8 and MacArthur Foundation 92/21848, coordinated by M. Almeida, M. Cunha and K. Brown (UNICAMP / USP).

The interview effort aimed to sample $20 \%$ of the riverine families living by the riverbanks: for every household interviewed, the next four were skipped. At the time of the interview, the UJER included about 865 families, 47\% inhabiting the banks of the rivers (Almeida, 1991; Asareaj, 1993). With the exception of the Breu River, most interviews were done with women, as they were more commonly found at home, as men were often fishing or working the cassava (Manihot esculenta) fields (details in Begossi et al., 1999 and 2020). Interviews were carried out at homes, but individually, and questions included fish consumed and fish preferred, among others.

Fish was collected through donations from fishermen and by experimental fisheries using gillnets with varied mesh sizes (Silvano et al., 2000). Collected fish was fixed in $10 \%$ formaldehyde, stored in a plastic container and identified by B. D. Amaral, RAM Silvano and Oswaldo T. Oyakawa and deposited at MZUSP (Museu de Zoologia da Universidade de São Paulo). The fish identification and fishing methods have been published elsewhere (Begossi et al.,, 1999; Silvano et al.,, 2000, 2001).

\section{Results}

The data for the main and major rivers, Juruá and its tributary Tejo, are grouped. The streams and smaller rivers are analyzed separately, as they occupy a more remote position, making it possible to check local differences. Interviews included 133 individuals, divided by river as: Juruá and Tejo (94 individuals), Bagé (16), Igarapé São João (16), and Breu (7) (Table 1). Among these, 77 are women and 56 are men (Table 1 ). Interviewees were on average 32.5 years old, ranging from 15 to 77 (Table 1 ). For other details see Begossi et al., (2020). In fact, in two of the rivers, Igarapé São João and Breu, none of the interviewees were born in the community where they resided. With the exception of two people, the remaining interviewees were illiterate or functional illiterate (Table 1 ).

Activities included fishing, hunting and agriculture, mostly performed by men, and some fishing, agriculture, handicrafts (baskets, for example), processing of manioc flour, agriculture, and house-keeping, by women. However, some activities had the participation of both men and women, such as net crafting and manioc flour production.

\subsection{Agriculture}

Out of the 133 interviewed households, 90 families practiced agriculture by cultivating cassava, rice, beans, corn and tobacco, among others (Table 2). At the Juruá / Tejo Rivers (66 families interviewed) and at the Breu (4 families) the most cultivated item were beans. At the Bagé River (10 families), corn was the most important item, while at the Igarapé São João (10 families) cassava, beans and tobacco were the most important items (Table 2). At the time of the interview, access to commerce and trading points were one of the limiting factors for the local people. Families at the Juruá river also cultivated tobacco.

Table 1. Socioeconomic characteristics of interviewees at the Upper Juruá Extractive Reserve (n=133), in 1993/1994.

\begin{tabular}{lcccc}
\hline \multicolumn{1}{c}{ Characteristic } & Juruá/Tejo & Bagé & Igarapé São João & Breu \\
\hline Sex (F/M) & $55 / 39$ & $10 / 6$ & $9 / 7$ & $3 / 4$ \\
Average (range) & $34.5(15-77)$ & $34.7(15-66)$ & $22.8(18-37)$ & $38(20-58)$ \\
Born in the same village (\%) & $10.6 \%$ & $18.8 \%$ & $0 \%$ & $0 \%$ \\
Education level & & & 13 & 5 \\
Illiteracy (0-1 year) & 78 & 10 & 1 & 1 \\
Functional illiteracy (up to 4 years) & 12 & 1 & 0 & \\
Literate & 2 & 0 & & \\
\hline
\end{tabular}

${ }^{*}$ people studied up to the $8^{\text {th }}$ elementary grade, which was the maximum registered in the communities. 
Table 2. Main items cultivated by the riverine inhabitants of the Upper Juruá Extractive Reserve (shown by river communities: columns) ( $\mathrm{n}=90$ interviews, 1993-1994). The colors represent the relevance of each cultivar to the village (darkest gray $=>50 \%$ of the families in the village practice it; second darkest $=30-50 \%$; followed by $15-29.9 \% ; 5-14.9 \% ; 1-4.9 \%$; and 0 in white)

\begin{tabular}{lccccc}
\hline Agriculture & $\begin{array}{c}\text { Juruál } \\
\text { Tejo }\end{array}$ & Bagé & $\begin{array}{c}\text { São } \\
\text { João }\end{array}$ & Breu & Total \\
\hline Avocado & 2 & 0 & 0 & 0 & 2 \\
Banana & 23 & 4 & 1 & 2 & 30 \\
Bean & 54 & 3 & 7 & 4 & 68 \\
Cabbage & 2 & 1 & 0 & 0 & 3 \\
Chili & 2 & 1 & 0 & 0 & 3 \\
Coffee & 1 & 0 & 0 & 0 & 1 \\
Corn & 36 & 10 & 4 & 3 & 53 \\
Green & 2 & 0 & 0 & 0 & 2 \\
produce & & & & & \\
Herbs and & 2 & 0 & 0 & 0 & 2 \\
spices & 0 & 0 & 1 & 0 & 1 \\
Lime & 1 & 0 & 0 & 0 & 1 \\
No data & 3 & 0 & 0 & 0 & 3 \\
Onion & 1 & 0 & 0 & 0 & 1 \\
Orange & 3 & 1 & 1 & 0 & 5 \\
Papaya & 6 & 0 & 0 & 0 & 6 \\
Potato & 4 & 1 & 0 & 0 & 5 \\
Pumpkin & 27 & 8 & 6 & 2 & 43 \\
Rice & 50 & 9 & 7 & 3 & 69 \\
'Roça' & 12 & 3 & 2 & 1 & 18 \\
(Cassava) & 5 & 2 & 7 & 2 & 46 \\
Sugar cane & 1 & 0 & 0 & 1 \\
Tobacco & 35 & 1 & 0 & 0 & 5 \\
Tomato & 0 & & & & \\
Watermelon & 4 & & & \\
\hline & & & & & \\
& & & & & \\
\hline
\end{tabular}
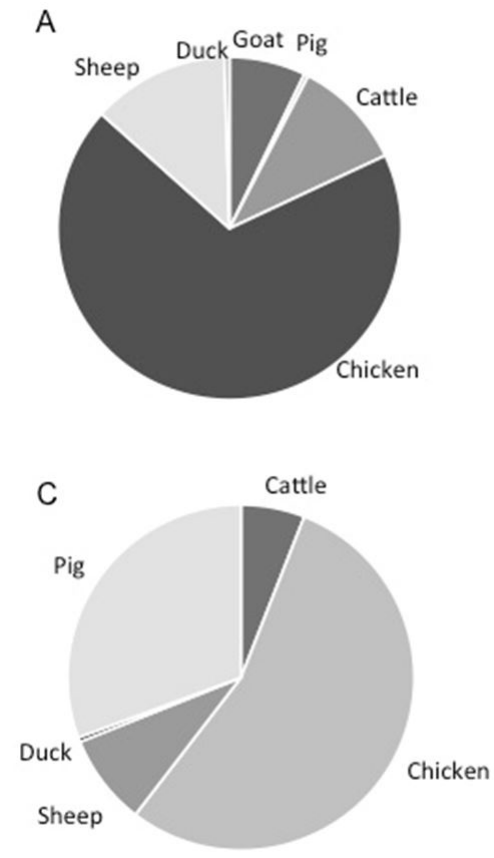

\subsection{Animal breeding}

A total of 90 families provided information on animal breeding: 66 in the Tejo/Juruá, 10 in the Bagé, 10 in São João and four in Breu. In the Tejo/Juruá, most families raised chickens and several raised pigs, goats, sheep and cattle. Cattle were commonly sighted along the banks of the Juruá River, at the time of the interviews. Cattle were also common on the three other riverbanks (Figure 2).

\subsection{Hunting and fishing}

Game hunting at UJER occurs especially in the winter (September-March), when the river water level is high and fishing becomes less productive. Although fishing happens year-round, it is more common in the summer, when the river water level is low and fish is more concentrated. Thus, it makes sense that, among 118 respondents, 105 said to consume more fish during the summer and 92 said to consume more game in the winter.

Hunting was addressed in Begossi et al., (1999) and shows brocket deers, peccaries, coatis, nhambus (tinamid bird), monkeys, cotias, among others, as being important for the local diet. "Imbiara" (birds and small rodents, see Begossi et al.,, 1999) was mentioned by men and women (Table 3).

The fishing equipment or gear used by riverine people included mainly hook and line, castnet, and gillnet. The vessels included mainly canoes, especially rowing in paddled canoes (Table 4 ). We did not identify any family that sold their fish $(n=74)$.

\subsection{Fish consumption at UJER}

Ninety-nine families informed about their fish consumption. Fish, especially bode (family Loricariidae)

B
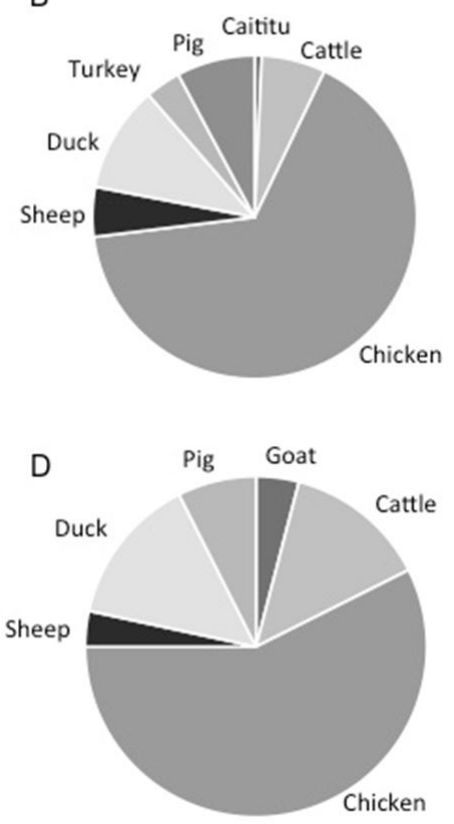

Figure 2. Data on animal husbandry (1993/1994, average): A) Juruá and Tejo rivers, B) Bagé River, C) Igarapé São João and D) Breu River. 
Table 3. Game consumption at the Upper Juruá Extractive Reserve ( $n=118$ interviews, 70 women and 48 men, 1993-1994). Identification found in Begossi et al. (1999) and MMA, 2009.

\begin{tabular}{|c|c|c|c|c|}
\hline Popular name & Species & Women & Men & Total \\
\hline \multicolumn{5}{|l|}{ Mammals } \\
\hline Tapir & Tapirus terrestris & 2 & 2 & 4 \\
\hline Cotia & Dasyprocta fuligonosa & 10 & 13 & 23 \\
\hline Cuties & Myoprocta pratti & 1 & 0 & 1 \\
\hline Armadillo & Cingulata & 4 & 1 & 5 \\
\hline Deer & Mazama spp. & 17 & 28 & 45 \\
\hline Monkey & $\mathrm{NI}$ & 5 & 13 & 18 \\
\hline Capuchin monkey & Cebus apella & 0 & 5 & 5 \\
\hline Spider monkey & Ateles paniscus & 1 & 1 & 2 \\
\hline Howler monkey & Alouatta seniculus & 1 & 5 & 6 \\
\hline Coati & Nasua nasua & 12 & 16 & 28 \\
\hline Squirrel & Sciurus spp. & $? ?$ & $? ?$ & $? ?$ \\
\hline Agouti & Cuniculus paca & 6 & 4 & 10 \\
\hline Peccaries & Pecari tacaju, Tayassu pecari & 16 & 23 & 39 \\
\hline Imbiara & NI rodent & 20 & 17 & 37 \\
\hline \multicolumn{5}{|l|}{ Birds } \\
\hline Jacu & $\mathrm{NI}$ & 3 & 5 & 8 \\
\hline Nambu & Crypturellus and Tinamus spp. & 9 & 18 & 27 \\
\hline Parrots & Amazona spp. and Pionus spp. & 1 & 1 & 2 \\
\hline Aracua & $\mathrm{NI}$ & 0 & 1 & 1 \\
\hline Capitão & Capito spp. & 1 & 0 & 1 \\
\hline \multicolumn{5}{|l|}{ Reptiles } \\
\hline Jaboti & Chelonioidis denticulata & 1 & 1 & 2 \\
\hline
\end{tabular}

NI=not identified.

Table 4. Fishing Gear used by riverine inhabitants of UJER ( $n=66)$.

\begin{tabular}{lccccc}
\hline Gear & Juruá & Tejo & Bagé & São João & Breu \\
\hline Cast net & 41 & 16 & 1 & 9 & 2 \\
Hook and line & 9 & 10 & 2 & 3 & 2 \\
Gillnet & 0 & 0 & 3 & 0 & 0 \\
Bicheiro (small harpoon) & 0 & 2 & 0 & 0 & 0 \\
No data & 2 & 0 & 0 & 1 & 1 \\
\hline
\end{tabular}

and mandi (families Pimelodidae and Auchenipteridae), were the main fish consumed by the inhabitants of the UJER. The main list of fish consumed by the riverine inhabitants of UJER can be found in Table 5. Information about the fish consumption at the UJER was published in Begossi et al., (1999) and Silvano et al., (2001). Here we focus especially on gender differences or preferences in fish consumption in the different seasons (summer/winter).

Results from men and women were obtained partially in different residences and partially in the same residence. The two main group of species mentioned before, bode and mandi, are consumed all year long. Still, there were some differences regarding the winter and summer fish. For the summer, at the Juruá/Tejo rivers women mentioned the consumption of bicuda (not collected, but possibly Boulengerella spp., see Silvano 2020), cuiú (Pterodoras granulosus), curimatá (Prochilodus sp.), mocinha (Potamorhina altamazonica) and moela (Pimelodina flavipinnis), while men said to consume piramutaba (Platysilurus barbatus, Callophysus macropterus) and surubim (Pseudoplatystoma spp.) (Table 5). At the Bagé river, women cited seven species of fish, besides mandi and bode, whereas men mentioned mandi and bode. At Igarapé São João, women focused on mandi, casca grossa and curimatá and men consumed more Jundiá and sardinha; bode and mandi were consumed by both women 
and men, but especially by the latter ( $80 \%$ of citations). At the Breu river, women mentioned mandi, bode and surubim, whereas men focused on curimata, piaba and sardinha (Figure 3).

During the winter, at the Juruá/Tejo rivers women consumed especially mandi, bicuda, curimata, gordinho and sabonete (both not collected) whereas men consumed proportionately more casca grossa, mocinha, pescada, piramutaba, traíra (Hoplias aff. malabaricus), among others (Table 5). At the Bagé river, women consumed nine species, whereas men focused on cará; at Igarapé São João, bode was more consumed by women and mandi slightly more by men. At Breu river, men consumed more bode, compared to women that consumed more mota (Figure 3).
A) Juruá/Tejo (52W/38M)
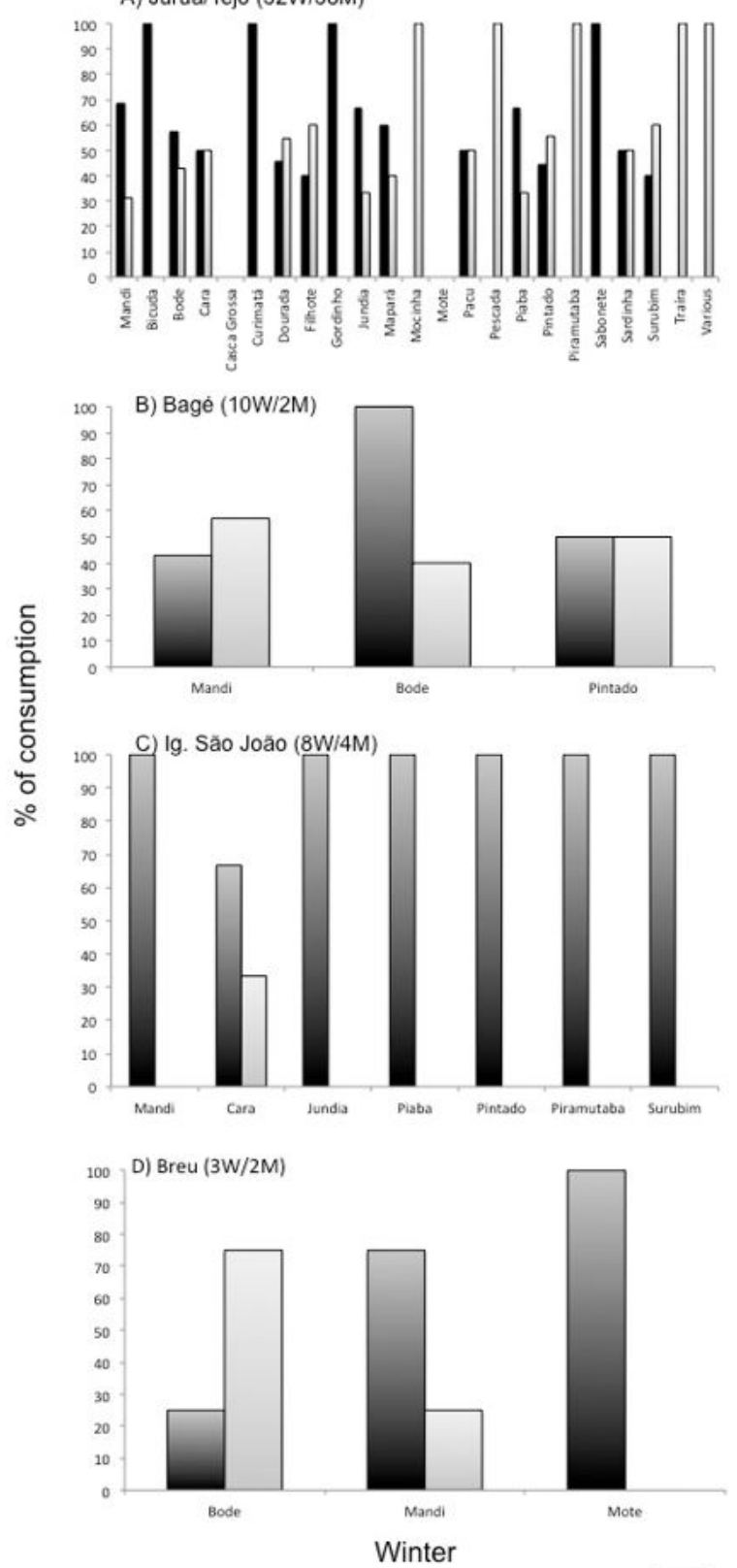
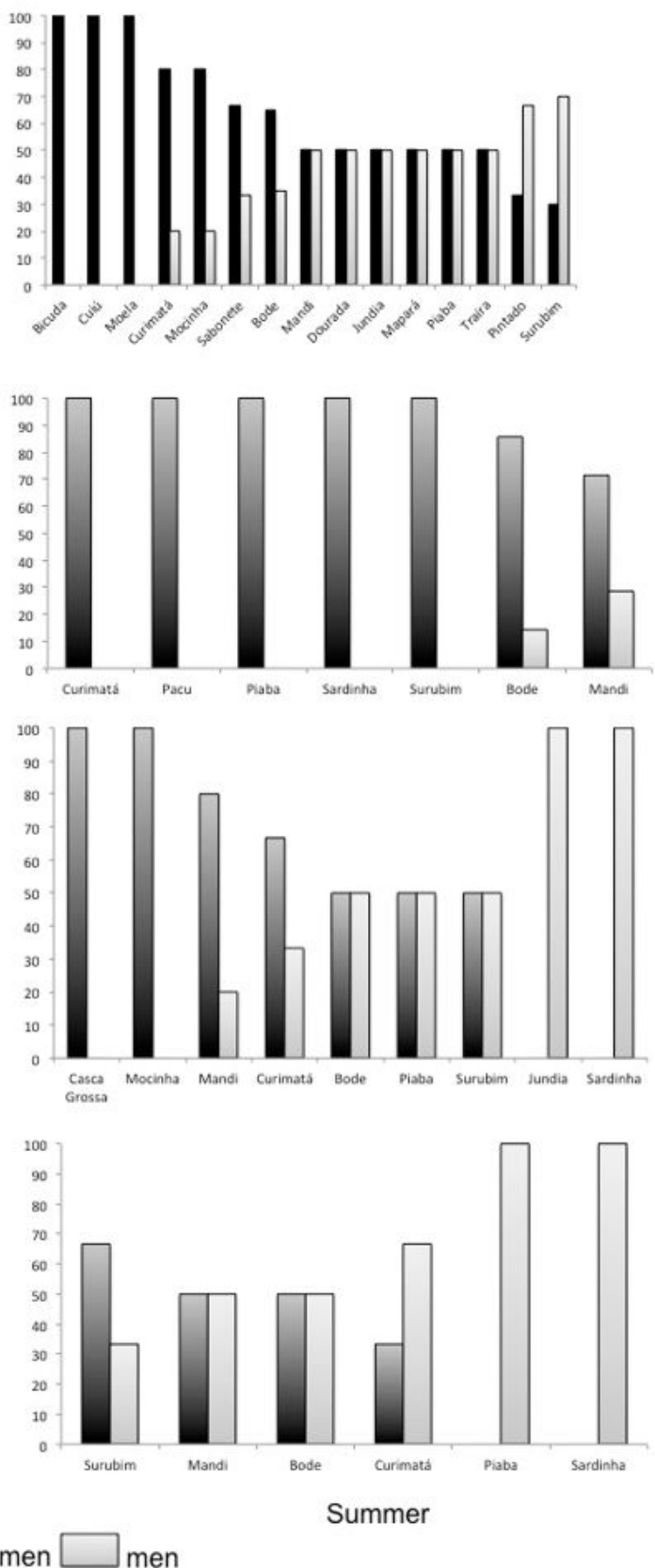

Figure 3. Percentage of citation about fish consumption in the winter (high water, rainy season, September-March) and in the summer (low water, dry season, April-August), by women (73 interviews) and men (46 interviews), at UJER. 1993/1994. 
Table 5. Main fish, with identification of the main species mentioned at interviews at the Upper Juruá Extractive Reserve (1993/1994). Identification is found in Begossi et al. (1999) and Silvano et al. (2001).

\begin{tabular}{ll}
\hline Local name & \multicolumn{1}{c}{ Species identification } \\
\hline Bico de pato & Sorubim lima \\
Bicuda & Not collected, but possibly \\
& Boulengerella spp. \\
Bode & Loricariidae, many species \\
Cará & Hypselacara temporalis, Aequidens sp. \\
Casca-grossa & Psectrogaster spp. \\
Cuiu & Oxydoras niger \\
Curimatá & Prochilodus nigricans \\
Dourada & Not collected \\
Gordinho & Not collected \\
Mocinha & Potamorhina altamazonica \\
Filhote & Not collected \\
Jundiá & Brachyplatystoma juruense \\
Mandi & Pimelodidae and Auchenipteridae \\
Moela & Pimelodina flavipinnis \\
Mota & Brachyplatystoma vaillanti \\
Pescadinha & Pachyurus sp., Plagioscion spp. \\
Piaba & Astyanax bimaculatus, \\
Piau & Curimatella imaculata, \\
Pintadinha & Steindachnerina spp. \\
Piranha & Anostomidae \\
Piramutaba & Calophysus macropterus \\
Sabonete & Pygocentrus nattereri, Serrasalmus spp. \\
Sardinha & Platysilurus barbatus, Callophysus \\
Surubim or pintado & macropterus \\
Traíra & Not collected \\
& Tetragonopterus argenteus, \\
& Triportheus spp. \\
Pseudoplatystoma spp. \\
Hoplias aff. malabaricus \\
\end{tabular}

\section{Discussion}

Data about the number of people living at the UJER is not sequential and it is variable. In 2001, population was of 4,615 people. Earlier information shows 860 families (Almeida, 1991; ASAREAJ, 1993, Maranho et al., 2015). Rezende (2010) shows the following population change: 1991 (865 houses), 1996 (639 houses) and 2005 (1163 houses); but, the number of inhabitants decreased from 5,387 in 1991 to 4,677 in 2005. Information on http://www.memorialchicomendes.org/resex-alto-jurua/ (May 13, 16:12) cites 7,500 residents at UJER. Finally, in 2010, Maranho et al., (2015) observed 1,500 families at the UJER and still a lack of infrastructure, such as school and of health post; the largest clusters were found in Restauração (Tejo River) and at the mouth of the Breu River. Our experience in the field research in 1993-1994 showed the beginning of the creation of the extractive reserve: at that time, basic economic problems soared, including the difficulties of selling tobacco, which was stored at home. There was no transportation, and residents complained that they were losing the harvest without selling it. Most people (90\%, Table 1$)$ were not born at their place of residence (the river specific location of their residences at the time of the interviews), but were born within the UJER limits, either in another community by the same river or by a different river. As a comparison, at the Lower Juruá Extractive reserve (Brasil, 2009), 57\% came from outside the reserve. At UJER, there is an intense inside migration, either among different rivers or localities, or among different places from the State of Acre (Ferreira, 2020). Ruiz-Perez et al., (2005) also observed internal displacement, showing that $93 \%$ of people that moved around stayed within the borders of the UJER.

Most of the UJER respondents were illiterate ( $80 \%$ functionally illiterate or totally illiterate, $n=124$ ) at the time of the interview. A few years later, at the Lower Jurua Extractive Reserve the education level was slightly higher than at UJER, since $13 \%$ studied the first year of basic school at the Lower Juruá (Brasil, 2009). The slight difference observed between the two regions could be due to the time difference between assessments: it is likely that the UJER education has undergone some improvements in 26 years, together with the remaining of the country. For example, the area close to Marechal Thaumaturgo (one of the towns within the UJER limits) has improved its primary and secondary education since 2000 (Landmann, 2014). Still, the very low level of education at the UJER could be partially due to the fact that this reserve is located in more remote areas of Amazonia, where there is an overall lack of infrastructure and schools.

Small-scale agriculture at UJER was represented especially by manioc (cassava), beans, tobacco, corn, rice and banana, among others (Table 2). Manioc is an important agricultural crop in Brazil, and in the state of Acre it represents $18 \%$ of the volume and $48 \%$ of the total gross production (Landmann, 2014). Manioc, the most important staple in Amazonia, and along with maize, were important crops since earlier Amazonian times (Sierra, 2016). Manioc is planted both in the wetland and upland environments; manioc flour and fish are key food items in the Amazonian context (Homma et al., 2012; Silva and Garavello, 2017).

We did not obtain data on rubber-tapping, which was still an important economic activity more than 10 years later (Ruiz-Pérez, 2005). Although tobacco was an important item at the Juruá river during our study, it was not listed as relevant in 2005 (Ruiz-Pérez, 2005). Tobacco may either have lost its relevance over time or it is a crop cultivated by specific communities eventually sampled by us, but not in other studies. Other activities, such as rubber extraction and the manufacture of plant-based leather have been studied and are not dealt with here; the manufacture of plant-based leather, for example, has been registered at the Bagé and Tejo rivers, among others (de Andrade, 2003).

Animal husbandry in the periods of 2005 (RuizPérez, 2005) and 2015 (Maranho et al., 2015) by the UJER families shows $94 \%$ of the families raising chicken, $52 \%$ livestock, $22 \%$ ducks and $15 \%$ pigs. These data are relatively in line with our 1993/1994 results, except for the fact that they suggest a significant increase in cattle breeding by 59\% at the UJER (Ruiz-Pérez et al., 2005). These authors also observed that pigs were used for both subsistence and commerce, whereas cattle were sold to areas outside the reserve. The increasing of cattle ranching in Amazonia is an 
imperative concern, due its strong potential to contribute with deforestation and greenhouse gas emission (zu Ermgassen et al., 2018; Bustamante et al., 2012).

\subsection{Game and Fish consumption}

The hydrological cycle of rivers in Amazonia supports and explains much of the variations in the local diet or in the subsistence/economic activities (Landmann, 2014).

The basic food staple at UJER is fish or game meat associated with manioc flour, which do not imply constant food availability. Families in the region deal with days of abundance and days with food shortages (Lozano, 1998). During fieldwork, we had the opportunity to share several meals with the riverine of UJER, most of which consisted of fish bode and cassava flour, although eventually we also shared deer broth with cassava flour, on the Tejo River. Hunting, carried out using various processes and techniques (Dias, 2004), provides meat, especially in the winter when the river floods and fish is less available (Begossi et al., 1999).

The most cited fish as food by the interviewees were bode and mandi (Figure 3). Silvano et al. (2001) emphasized that bode (Loricariidae) was cited by the riverine of the UJER by $56 \%$ as common and by $65 \%$ as consumed in the summer. These fish lack information about its ecology and biology and are categorized as NA (not accessed) in the UICN Red List and in the Brazilian Red list(Begossi et al., 2019). Therefore, studies are needed on these fish, especially when it is taken into account the food security of the ribeirinhos. Considering that the first and second quotes are different when coming from the same interviewee, we conclude that the importance of these small fish for the riverine diet is immense, since bode corresponds to $66 \%$ and mandí $61 \%$ of respondents (most consumed, first and second quotes, from Begossi et al., 2019). These are important data, as they show that even usually small fish, such as bode (Loricariidae), can guarantee the animal protein that sustains the population of riverine dwellers. The study on fish at UJER shows that bode (Hypostomus spp.) and mandi (Pimelodus spp.) are among the most abundant fish in sampling sites in the Juruá River (Silvano et al., 2000). This indicates that riverine people along the UJER has included some of the most common fish in their diets, which may be an adaptive strategy to secure a protein source, in case of variations on fish availability (Huntington et al., 2017). As fishing becomes more difficult in the winter because the rivers are flooded, people tend to turn to eating game (Figure 3 ). In the summer, fish get concentrated in ponds and lakes and are more easily caught (Silvano et al., 2000).

Both men and women mentioned several species of fish important in their food intake. Diversity of citations was slightly lower in the winter: women cited 29 fish in the winter and 33 in the summer. Men cited 23 fish in the winter and 27 in the summer. There is a slightly higher diversity of fish richness citation by women, as shown in Figure 3. In the literature of medicinal plants (ethnobotany), women also tend to cite a higher richness of medicinal plants, because they are often the ones that make the homemade medicines for the children in the form of tea or syrups, among others (Figueiredo et al., 1993). In the case of fish, it is also possible that women, when preparing the fish for consumption, have the chance to handle and carefully observe the fish, increasing their recording of species for either consumption or preferences. A gender biased in the interviews cannot be discarded either, as more women were interviewed here. According to Bailey (1982: 191) the sex of the interviewer probably affects the respondent's reaction. Such biases are sometimes reflected in responses given to please the interviewer of the same sex. The inverse also seems true, when less favorable responses are given to the interviewer of the opposite sex. However, gender bias in interviews seems to be more important in gender-related themes. Lipps and Lutz (2017) found that the gender of the interviewer influences on responses about general gender issues and on sensitive health issues, but it has no effect on political and on household tasks-related questions. In our case, interviews occurred most often in the presence of the couple, which likely counterbalances some gender-bias.

In spite of women and men showing preferences for some different species at the UJER, both consume scaly fish (peixe de escama) and smooth-skinned catfishes (peixe liso). In Amazonia, people tend to avoid peixe-liso: in Parintins, Amazonas State, $85,3 \%$ of the interviewees said to mainly prefer peixe de escama, whereas just $4 \%$ mentioned to prefer peixe liso (Costa et al., 2013). Flores et al. (2014) found genderdifference preferences, both including scaly fish, such as caranha by men, and tucunaré by women. Other studies have shown no differences regarding the fish preferences by men and women, such as in the case of fishers of the Atlantic Forest coast (Begossi et al., 2012). In the case of the UJER, food taboos, locally called fish reimoso, include several scaleless fish (called peixes de couro), but one scaly fish, the curimata(Begossi et al., 1999). Many hypotheses try to explain fish food taboos in Amazonia, some more psychological and symbolic (Leme, 2007) and others more cultural-ecological (Begossi et al., 2004), among others. In particular, Begossi et al. (2004) discuss in detail several hypotheses to explain food taboos, including data from the UJER, among other Amazonian sites.

\subsection{Looking at other protected sites: co-management and conservation}

Juruá is a highly productive river, where rural communities strongly rely on natural resources. Besides the Upper Juruá Extractive Reserve, there are other sustainableuse Protected Areas and two Indigenous areas at the Juruá river basin. In these areas, fisheries co-management comprises one of the most important networks, strongly contributing with food security, income generation and protection of floodplains habitats (Campos-Silva et al., 2019; Braga, 2011). In addition, co-managements have been strongly contributing with conservation of fish stocks and local development, while also promoting the recovery of non-target populations (Campos-Silva and Peres, 2016).

\subsection{The Middle Juruá: lessons to be learned}

In this session, we use information from the Middle Juruá Extractive Reserve in order to provide thoughts about management possibilities at UJER. We use here, as an example, the pirarucu (Arapaima spp.) management, which is a common species at the Middle Juruá River. Information about community-based management in the Middle Juruá river can provide tools for managing areas of the UJER, towards other fish species, as we did not collect any pirarucu at UJER during our fieldwork.

In the middle region of the Juruá river, hunting and fishing are complementary activities to ensure the food security 
of local dwellers, as we also observed at UJER. The average extraction rate of game and fish species varies between approximately $30 \mathrm{~g}$ and $1,500 \mathrm{~g}$ per person per day, respectively (Endo et al., 2016). These activities are partially regulated by the flood pulse. During flooding and especially at the peak of the high water season, fishing is negatively impacted and the catch per unit effort is reduced, whereas hunting gains relevance with increased yields. The alternation of activities is a compensatory mechanism that helps ensure the food security (Endo et al., 2016). A similar pattern of alternation between fishing during the dry season and hunting during the flood season was also observed at UJER (Begossi et al., 1999).

Co-management of pirarucu (Arapaima gigas) fisheries is also an emblematic activity at Middle Juruá River. The pirarucu is one of the most important fishes in Amazonia basin, representing a high-value resource since pre-Columbian societies (Prestes-Carneiro et al., 2016). The long history of subsistence and commercial overfishing colapsed wild populations in many parts of Amazonia and the species was included in CITES list (Castello and Stewart, 2010). However, in the last 20 years, rural communities in close partnership with researchers developed an inovative model, based on the protection of floodplains habitats and harvesting quotas (Castello et al., 2009). The ecological outcomes from this fishery co-management model are impressive. In Middle Juruá River fisheries co-management induced population recoveries of pirarucu by $425 \%$ in 11 years (CamposSilva et al., 2019). Protected lakes ensure a population 30 fold higher than unprotected environments, even outside formal Protected Areas. This example can provide insights for the management of other species in the UJER, which are important for the food security of the ribeirinhos. Managing pirarucu at the Upper Juruá, in a manner similar to what is done in the Middle Juruá, may not be a possibility if the species does not commonly occur there (we did not observe pirarucu at the UJER). Nevertheless, suggestions for the management of other common species could generate interesting perspectives for the local population. For example, jundiá (Brachyplatystoma juruense), mapará (Hypophthalmus edentatus) and other species of large catfish could be promising options for management, since they were common at the UJER and they are generally well accepted for commerce. Although promising, the management of large catfish may be challenging, as these fish undergo long migrations and may be thus caught by different communities along the Amazonian rivers (Hallwass and Silvano, 2016).

Co-management of fisheries at the Middle Jurua river has also been reducing gender inequality on fishing(Freitas et al., 2020a). Women have always been involved in fishing, but very often underpaid due to a strong invisibility (Gustavsson and Riley, 2018). However, the pirarucu co-management fishery performed at the Middle Juruá River has been inducing a substantial social transformation on women participation on fishing, as this fishery model represents an innovative source income for women and an unprecedented increasing on women participation in decision-making (Freitas et al., 2020a,b).

\section{Environmental changes}

Although the system described above (for the UJER and including comparisons to the Middle Juruá) is in the same river basin, co-management should not be seen as a panacea to any eventual environmental problem in the region. It is important to stay ecologically alert, even regarding remote areas of Amazonia, such as the region where the Upper Juruá is located. The whole Amazonia is under soaring pressure from deforestation and large developmental projects, and the potential effects of these impacts are not restricted to main commercial fish, but also to fish used only for local subsistence (Begossi et al., 2019). There are multiple projects for hydroelectric dam construction in the entire Amazonia, including in its headwaters, which should have devastating consequences on fish diversity and productivity, by blocking fish migration, for example (Winemiller et al., 2016). These headwater dams should also impact the hydrology and sediment load of Amazonian rivers, with likely consequences on fisheries and small agriculture of the riverine people (Forsberg et al., 2017; Latrubesse et al., 2017). Local fishers from different river basins in Amazonia have noted several impacts from dams on the aquatic fauna and on the local fishery (Hallwass et al., 2013a, Santos et al., 2020). Deforestation of floodplains may also affect fish communities and decrease productivity of local fisheries in the Brazilian Amazonia (Arantes et al., 2018; Castello et al., 2018). However, the potential effects from deforestation or from land use on fish communities and small-scale fisheries are not known in upstream rivers, such as in the upper Juruá, where the UJER is located.

\section{Conclusions}

Our results, in comparison with other studies at other time periods in the Upper Juruá River, indicate that fish, including smaller fish species, and game are important food sources for the reserve dwellers. There is a seasonal variation in the consumption of these food sources and the comparison with the Middle Jurua suggests promising ideas for developing fisheries co-management, which may be adapted to the reality of UJER. However, deforestation and development projects could also be a threat to fish and fisheries at the studied extractive reserve.

\section{Acknowledgements}

We are grateful to the people from UJER who collaborated with our study. To the MacArthur Foundation and FAPESP, supporters of this study, coordinated by M. Almeida, M.C. Cunha and K.S. Brown. AB, PFML, and RAMS are grateful for their productivity scholarships from the Conselho Nacional de Desenvolvimento Científico e Tecnológico (CNPq \# 301592/2017-9, 301515/2019-0, and 303393/20190 , respectively), from the Coordenação de Aperfeiçoamento de Pessoal de Nível Superior (RAMS, CAPES-PRINT, grant 88887.467553/2019-00), and J.V.C.-S. acknowledges his postdoc position (grant no. 295650) funded by Belmont Forum and BiodivERsA joint call for research proposals, under the BiodivScen ERA-Net COFUND programme, and with the funding organizations French National Research Agency (ANR), São Paulo Research Foundation (FAPESP), National Science Foundation (NSF), the Research Council of Norway and the German Federal Ministry of Education and Research (BMBF). 


\section{References}

ALMEIDA, M.W.B. and MENEZES, M.A., 1994. O destino da Floresta. Rio de Janeiro: Dumará Distribuidora de Publicações Ltda. Reserva Extrativista do Alto Juruá, pp. 165-225.

ALMEIDA, M.W.B., 2004. Direitos à floresta e ambientalismo: seringueiros e suas lutas. Revista Brasileira de Ciências Sociais, vol. 19, no. 55, pp. 33-53. http://dx.doi.org/10.1590/S010269092004000200003.

ALMEIDA, O.T., LORENZEN, K. and MCGRATH, D.G., 2009. Fishing agreements in the lower Amazon: for gain and restraint. Fisheries Management and Ecology, vol. 16, no. 1, pp. 61-67. http://dx.doi. $\operatorname{org} / 10.1111 / \mathrm{j} .1365-2400.2008 .00647 . x$.

ALMEIDA, W.B., 1991. Levantamento sócio-economico Reserva Extrativista do Alto Juruá. Acre: ASAREAJ. Available from: https://acervo. socioambiental.org/sites/default/files/documents/K0D00104.pdf.

ARANTES, C.C., FITZGERALD, D.B., HOEINGHAUS, D.J. and WINEMILLER, K.O., 2019. Impacts of hydroelectric dams on fishes and fisheries in tropical rivers through the lens of functional traits. Current Opinion in Environmental Sustainability, vol. 37, pp. 28-40. http://dx.doi.org/10.1016/j.cosust.2019.04.009.

ARANTES, C.C., WINEMILLER, K.O., PETRERE, M., CASTELLO, L., HESS, L.L. and FREITAS, C.E.C., 2018. Relationships between forest cover and fish diversity in the Amazon River floodplain. Journal of Applied Ecology, vol. 55, no. 1, pp. 386-395. http:// dx.doi.org/10.1111/1365-2664.12967.

ASSOCIAÇÃO DE SERINGUEIROS E AGRICULTORES DA RESERVA EXTRATIVISTADO ALTOJURUÁ-ASAREAJ.Coordenação: Mauro W.B. de Almeida. 1993. CADASTRODEMORADORES-1991. Acre: ASAREAJ.

BAILEY, K.D., 1982. Methods of social research. London: The Free Press, $553 \mathrm{p}$.

BEGOSSI, A. and BROWN, D., 2003. Experiences with fisheries management in Latin American and the Caribbean. In: D.C. WILSON, J.R. NIELSEN and P. DEGNBOL. The fisheries comanagement experience. Dordrecht: Kluwer Academic Pub. pp. 135-152. http://dx.doi.org/10.1007/978-94-017-3323-6_9.

BEGOSSI, A., 2001. Cooperative territorial resources: Brazilian artisanal fisheries. In: J. BURGER, E. OSTROM, R.B. NORGAARD, D. POLICANSKY and B.D. GOLDSTEIN, Protecting the commons. Washington, DC: Island Press, pp. 109-132.

BEGOSSI, A., FERREIRA, R. and SILVANO, R. A. M., 2020. Ribeirinhos do Alto Juruá. São Carlos: NEPA/UNICAMP, FIFO, RIMA.

BEGOSSI, A., HANAZAKI, N. and ROSSANO, R.R., 2004. Food Chain and the reasons for fish food taboos among Amazonians and Atlantic Forest Fishers (Brazil). Ecological Applications, vol. 14, no. 5, pp. 1334-1343. http://dx.doi.org/10.1890/03-5072.

BEGOSSI, A., SALIVONCHYK, S.V., HALLWASS, G., HANAZAKI, N., LOPES, P.F.M., SILVANO, R.A.M., DUMARESQ D. and PITTOCK, J., 2019. Fish consumption on the Amazon: A review of biodiversity, hydropower and food security issues. Brazilian Journal of Biology = Revista Brasileira de Biologia, vol. 79, no. 2, pp. 345-357. http:// dx.doi.org/10.1590/1519-6984.186572. PMid:30379202.

BEGOSSI, A., SALIVONCHYK, S.V., HANAZAKI, N., MARTINS, I.M. and BUELONI, F., 2012. Fishers (Paraty, RJ) and fish manipulation time: a variable associated to the choice for consumption and sale. Brazilian Journal of Biology = Revista Brasileira de Biologia, vol. 72, no. 4, pp. 973-975. http://dx.doi.org/10.1590/S151969842012000500030. PMid:23295533.

BEGOSSI, A., SILVANO, R.A.M., AMARAL, B.D. and OYAKAWA, O.T., 1999. Uses of fish and game by inhabitants of an extractive reserve (Upper Juruá, Acre, Brazil). Environment, Development and Sustainability, vol. 1, no. 1, pp. 73-93. http://dx.doi. org/10.1023/A:1010075315060.
BRAGA, T.M.P., 2011. Conhecimento local ribeirinho e suas aplicações para o manejo participativo da pesca na Reserva Extrativista do baixo Juruá, estado do Amazonas. Manaus: Instituto Nacional de Pesquisas da Amazônia. Tese de Doutorado.

BRASIL. MINISTÉRIO DO MEIO AMBIENTE. INSTITUTO CHICO MENDES DE CONSERVAÇÃO DA BIODIVERSIDADE, 2009. Plano de Manejo da Reserva Extrativista do Baixo Juruá. Juruá, AM: MMA.

BUSTAMANTE, M.M., NOBRE, C.A., SMERALDI, R., AGUIAR, A.P., BARIONI, L.G., FERREIRA, L.G. and OMETTO, J.P., 2012. Estimating greenhouse gas emissions from cattle raising in Brazil. Climatic Change, vol. 115, no. 3-4, pp. 559-577. http://dx.doi.org/10.1007/ s10584-012-0443-3.

CAMPOS-SILVA, J.V. and PERES, C.A., 2016. Community-based management induces rapid recovery of a high-value tropical freshwater fishery. Scientific Reports, vol. 6, no. 1, pp. 34745. http://dx.doi.org/10.1038/srep34745. PMid:27731319.

CAMPOS-SILVA, J.V., HAWES, J.E. and PERES, C.A., 2019. Population recovery, seasonal site fidelity, and daily activity of pirarucu (Arapaima spp.) in an Amazonian floodplain mosaic. Freshwater Biology, vol. 64, no. 7, pp. 1255-1264. http://dx.doi.org/10.1111/ fwb.13301

CARVALHO, J.M., 1997. Mandonismo, coronelismo, clientelismo: uma discussão conceitual., Dados, vol. 40, no. 2, pp. 229-250. http://dx.doi.org/10.1590/S0011-52581997000200003.

CASTELLO, L. and STEWART, D.J., 2010. Assessing CITES nondetriment findings procedures for Arapaima in Brazil. Journal of Applied Ichthyology, vol. 26, no. 1, pp. 49-56. http://dx.doi. org/10.1111/j.1439-0426.2009.01355.x.

CASTELLO, L., HESS, L.L., THAPA, R., MCGRATH, D.G., ARANTES, C.C., RENÓ, V.F. and ISAAC, V.J., 2018. Fishery yields vary with land conver on the Amazon River floodplain. Fish and Fisheries, vol. 19, no. 3, pp. 431-440. http://dx.doi.org/10.1111/faf.12261.

CASTELLO, L., MCGRATH, D.G., HESS, L.L., COE, M.T., LEFEBVRE, P.A., PETRY, P., MACEDO, M.N., RENÓ, V.F. and ARANTES, C.C., 2013. The vulnerability of Amazon freshwater ecosystems. Conservation Letters, vol. 6, no. 4, pp. 217-229. http://dx.doi. org/10.1111/conl.12008.

CASTELLO, L., VIANA, J.P., WATKINS, G., PINEDO-VASQUEZ, M. and LUZADIS, V.A., 2009. Lessons from integrating fishers of arapaima in small-scale fisheries management at the Mamirauá Reserve, Amazon. Environmental Management, vol. 43, no. 2, pp. 197-209. http://dx.doi.org/10.1007/s00267-008-9220-5. PMid:18946698.

CASTILLA, J.C. and DEFEO, O., 2001. Latin American benthic shellfisheries: emphasis on co-management and experimental practices. Reviews in Fish Biology and Fisheries, vol. 11, no. 1, pp. 1-30. http://dx.doi.org/10.1023/A:1014235924952.

CASTRO, F. and MCGRATH, D., 2003. Moving toward sustainability in the local management of floodplain lake fisheries in the Brazilian Amazon. Human Organization, vol. 62, no. 2, pp. 123133. http://dx.doi.org/10.17730/humo.62.2.9bkh58xeekj6bg0m.

COSTA, A. C. S.; SOUZA, L.P, DELGADO, R. C. and GOMES, F. A., 2012. Períodos de cheia e vazante do Rio Juruá na região de Cruzeiro do Sul, Acre. Enciclopédia Biosfera, Centro Científico Conhecer, vol. 8, no. 14, pp. 1343.

COSTA, T.V., SILVA, R.R.S., SOUZA, J.L., BATALHA, O.S. and HOSHIBA, M.A., 2013. Aspectos do consumo e comércio do pescado em Parintins. Boletim do Instituto de Pesca, vol. 39, no. 1, pp. 63-75.

DE ANDRADE, A.A.L.G., 2003. Artesãos da floresta, população e inovação tecnologica: o caso do "couro vegetal" na reserva extrativista do Alto Jurua, Acre. Campinas: UNICAMP, 174 p. Dissertacão de Mestrado.

DIAS, C.J. 2004. Na Floresta onde vivem mansos vivem brabos: economia simbólica de acesso a natureza praticada na Reserva Extrativista do Alto Juruá. Campinas: UNICAMP, 262 p. Tese de Mestrado. 
ENDO, W., PERES, C.A. and HAUGAASEN, T., 2016. Flood pulse dynamics affects exploitation of both aquatic and terrestrial prey by Amazonian floodplain settlements. Biological Conservation, vol. 201, pp. 129-136. http://dx.doi.org/10.1016/j. biocon.2016.07.006.

FEARNSIDE, P.M. 2017a. Brazil's Belo Monte Dam: Lessons of an Amazonian resource struggle. Die Erde, vol. 148, no. 2-3, pp. 167-184. http://dx.doi.org/10.12854/erde-148-26.

FEARNSIDE, P.M. 2017b. Deforestation of the Brazilian Amazon. In: H. SHUGART, ed. Oxford Research Encyclopedia of Environmental Science. New York: Oxford University Press. http://dx.doi. org/10.1093/acrefore/9780199389414.013.102.

FEARNSIDE, P.M., 2001. Environmental impacts of Brazil's Tucuruî Dam: unlearned lessons for hydroelectric development in Amazonia. Environmental Management, vol. 27, no. 3, pp. 377 396. http://dx.doi.org/10.1007/s002670010156. PMid:11148764.

FEARNSIDE, P.M., 2007. Brazil's Cuiabá- Santarém (BR-163) Highway: The Environmental Cost of Paving a Soybean Corridor Through the Amazon. Environmental Management, vol. 39, no. 5, pp.601-614. http://dx.doi.org/10.1007/s00267-006-0149-2. PMid:17377730.

FERREIRA, J., ARAGÃO, L.E., BARLOW, J., BARRETO, P., BERENGUER, E., BUSTAMANTE, M., GARDNER, T.A., LEES, A.C., LIMA, A. LOUZADA, J., PARDINI, R., PARRY, L., PERES, C.A., POMPEU, P.S., TABARELLI, M. and ZUANON, J., 2014. Environment and Development. Brazil's environmental leadership at risk. Science, vol. 346, no. 6210, pp. 706-707. http://dx.doi.org/10.1126/ science.1260194. PMid:25378611.

FERREIRA, R.P., 2020. Reserva Extrativista Alto Juruá, comparações temporais 1993/1994 - 2020 e segurança alimentar das comunidades ribeirinhas. Santos: Universidade Santa Cecília, Tese de Mestrado.

FIGUEIREDO, G.M., LEITÃO-FILHO, H.F. and BEGOSSI, A., 1993. Ethnobotany of Atlantic Forest Coastal Communities: Diversity of Plant Uses in Gamboa (Itacuruçá Island, Brazil). Human Ecology, vol. 21, no. 4, pp. 419-430. http://dx.doi.org/10.1007/ BF00891142.

FLÔRES, R.M.V., CHICRALA, P.M. and SOARES, S.S., 2014. Avaliação das preferências dos consumidores de pescado do Estado do Tocantins através de pesquisa de campo realizada no seminário caiu na rede é lucro. Brazilian Journal of Aquatic Science and Technology, vol.18, no. 1, pp. 121-129. http://dx.doi.org/10.14210/ bjast.v18n1.p121-129.

FORSBERG, B.R., MELACK, J.M., DUNNE, T., BARTHEM, R.B., GOULDING, M., PAIVA, R.C.D., SORRIBAS, M.V., SILVA JUNIOR, U.L., and WEISSER, S., 2017. The potential impact of new Andean dams on Amazon fluvial ecosystems. PLoS One, vol. 12, no. 8, pp. e0182254. http://dx.doi.org/10.1371/journal.,pone.0182254. PMid:28832638.

FREITAS, C.T., ESPÍRITO-SANTOS, H.M.V., CAMPOS-SILVA JOÃO VICTOR, B., PERES, C.A. and LOPES, P.F.M., 2020a. Comanagement: a potential tool to promote gender equity in fisheries. Ecological Economic, vol. 176, pp. 106709.

FREITAS, C.T., LOPES, P.F.M., CAMPOS-SILVA, J.V., NOBLE, M.M., DYBALL, R. and PERES, C.A., 2020b. Co-management of culturally impor- tant species: A tool to promote biodiversity conservation and human well-being. People and Nature, vol. 2, no. 1, pp. 6181. http://dx.doi.org/10.1002/pan3.10064.

FREITAS, J., 2012. Efeitos da intervenção governamental na Reserva Extrativista do Alto Juruá no período 1990 a 2010: identificação dos pontos fortes e fracos. Faculdade Federal do Amazonas. 131 p. Dissertação de Mestrado.

GOULDING, M., BARTHEM, R. and FERREIRA, E. 2003. The Smithsonian Atlas of The Amazon. Washington: Smithsonian books.
GUSTAVSSON, M., and RILEY, M.N., 2018. Women, capitals and fishing lives: exploring gendered dynamics in the Llŷn Peninsula small-scale fishery (Wales, UK). Maritime Studies, vol. 17, pp. 223-231.

GUTIÉRREZ, N.L., HILBORN, R. and DEFEO, O., 2011. Leadership, social capital and incentives promote successful fisheries. Nature, vol. 470, no. 7334, pp. 386-389. http://dx.doi.org/10.1038/ nature09689. PMid:21209616.

HALLWASS, G. and SILVANO, R.A.M., 2016. Patterns of selectiveness in the Amazonian freshwater fisheries: implications for management. Journal of Environmental Planning and Management, vol. 59, no. 9, pp. 1537-1559. http://dx.doi.org/ 10.1080/09640568.2015.1081587.

HALLWASS, G., LOPES, P.F., JURAS, A.A. and SILVANO, R.A.M., 2013a. Fishers' knowledge identifies environmental changes and fish abundance trends in impounded tropical rivers. Ecological Applications, vol. 23, no. 2, pp. 392-407. http://dx.doi. org/10.1890/12-0429.1. PMid:23634590.

HALLWASS, G., LOPES, P.F.M., JURAS, A.A. and SILVANO, R.A.M., 2011. Fishing effort and catch composition of urban market and rural villages in Brazilian Amazon. Environmental Management, vol. 47, no. 2, pp. 188-200. http://dx.doi.org/10.1007/s00267-0109584-1. PMid:21153639.

HALLWASS, G., LOPES, P.F.M., JURAS, A.A. and SILVANO, R.A.M., 2013 b. Behavioral and environmental influences on fishing rewards and the outcomes of alternative management scenarios for large tropical rivers. Journal of Environmental Management, vol. 128, pp. 274-282. http://dx.doi.org/10.1016/j.jenvman.2013.05.037. PMid:23764509.

HOMMA, A.K.O., ALVES, A.R., ALVES, S.M., FRANCO, A.A. and PENA, H.W.A. 2012. Environmental Sustainability in Agriculture and Food Security in the Brazilian Amazon. In: ISEE 2012 Conference, 2012. Rio de Janeiro, RJ. [accessed DAY MONTH YEAR]. Available from: https://www.alice.cnptia.embrapa.br/ bitstream/doc/952848/1/105homma.pdf

HUNTINGTON, H.P., BEGOSSI, A., GEARHEARD, S.F., KERSEY, B., LORING, P.A., MUSTONEN, T., PAUDEL, P.K., SILVANO, R.A.M. and VAVE, R., 2017. How small communities respond to environmental change: patterns from tropical to polar ecosystems. Ecology and Society, vol. 22, pp. 9.

ISAAC, V., ALMEIDA, M.C., GIARRIZZO, T., DEUS, C.P., VALE, R., KLEIN, G. and BEGOSSI, A., 2015. Food consumption as an indicator of the conservation of natural resources in riverine communities of the Brazilian Amazon. Anais da Academia Brasileira de Ciências, vol. 87, no. 4, pp. 2229-2242. http://dx.doi.org/10.1590/00013765201520140250 . PMid:26628023.

ISSAC, V. and ALMEIDA, M.C., 2011. El consumo de pescado en la Amazonía Brasileña. Rome: FAO. COPESCAALC Document no. 13.

KEPPELER, F.W., HALLWASS, G. and SILVANO, R.A.M., 2017. Influence of protected areas on fish assemblages and fisheries in a large tropical river. Oryx, vol. 51, no. 2, pp. 268-279. http://dx.doi. org/10.1017/S0030605316000247.

LANDMANN, R.D.V., 2014. “A Alagação não ofende”: a invisibilidade de um desastre relacionado às cheias atípicas na RESEX Alto Juruá, Acre. São Carlos: Universidade de São Paulo, 290 p. Tese de Doutorado.

LATRUBESSE, E.M., ARIMA, E.Y., DUNNE, T., PARK, E., BAKER, V.R., D'HORTA, F.M., WIGHT, C., WITTMANN, F., ZUANON, J., BAKER, P.A., RIBAS, C.C., NORGAARD, R.B., FILIZOLA, N., ANSAR, A., FLYVBJERG, B. and STEVAUX, J.C., 2017. Damming the rivers of the Amazon basin. Nature, vol. 546, no. 7658, pp. 363-369. http:// dx.doi.org/10.1038/nature22333. PMid:28617466. 
LEME, A.L., 2007. Comida de gente: preferências e tabus alimentares entre os ribeirinhos do Médio Rio Negro (Amazonas, Brasil). Revista de. Antropologia, vol. 50, no. 1, pp. 125-179. https://doi. org/10.1590/S0034-77012007000100004.

LIPPS, O., and LUTZ, G., 2017. Gender of interviewer effects in a multitopic centralized CATI panel survey. Methods, Data, Analyses, vol. 11, no. 1, pp. 67-86. https://doi.org/10.12758/mda.2016.009.

LOPES, P.F.M., SILVANO, R.A.M. and BEGOSSI, A., 2011. Extractive and Sustainable Development Reserves in Brazil: resilient alternatives to fisheries? Journal of Environmental Planning and Management, vol. 54, no. 4, pp. 421-443. http://dx.doi.or $\mathrm{g} / 10.1080 / 09640568.2010 .508687$.

LOZANO, E.M., 1998. Da patronagem a associação: poderes em disputa na reserva extrativista do Alto Juruá, Acre. Campinas: UNICAMP, 150 p. Dissertação de Mestrado.

LOZANO, E.M., 2010. Uma floresta politizada: relações políticas na Reserva Extrativista do Alto Juruá, Acre (1994-2002). Campinas: UNICAMP, 511 p. Tese de Doutorado.

LUNA, M.B.A. 2014. Questões do uso comum: transformações das lógicas de apropriação de territórios e recursos naturais. Campinas: UNICAMP, 212 p. Tese de Doutorado.

MACCORD, P.F.L., SILVANO, R.A.M., RAMIRES, M., CLAUZET, M. and BEGOSSI, A., 2007. Dynamics of artisanal fisheries in two Brazilian Amazonian reserves: implications to co-management. Hydrobiologia, vol. 583, no. 1, pp. 365-376. http://dx.doi. org/10.1007/s10750-006-0486-4.

MARANHO, S. A., LOPES, A. O. A. M. and SCARCELLO, M., 2015. Paradigmas e modo de vida nas reservas extrativistas: estudo de caso da Resex Alto Juruá no estado do Acre. In: Anais Do Congresso Brasileiro De Unidades De Conservação, Curitiba, 8 , CBUC: Curitiba. Trabalhos técnicos.

ORR, S., PITTOCK, J., CHAPAGAIN, A. and DUMARESQ D., 2012. Dams on the Mekong River: lost fish protein and the implications for land and water resources. Global Environmental Change, vol. 22, no. 4, pp. 925-932. http://dx.doi.org/10.1016/j. gloenvcha.2012.06.002.

PETRERE, M., 1996. Fisheries in large tropical reservoirs in South America. Lakes and Reservoirs: Research and Management, vol. 2, no. 1-2, pp. 111-133. http://dx.doi.org/10.1111/j.1440-1770.1996. tb00054.x.

PIMENTEL, D., MCNAIR, M., BUCK, L., PIMENTEL, M. and KAMIL, J., 1997. The value of forests to world food diversity. Human Ecology, vol. 25, no. 1, pp. 91-120. http://dx.doi. org/10.1023/A:1021987920278.

PRESTES-CARNEIRO, G., BÉAREZ, P., BAILON, S., PY-DANIEL, A.R. and NEVES, E.G., 2016. Subsistence fishery at Hatahara (750-1230 $\mathrm{CE})$, a pre-Columbian central Amazonian village. Journal of Archaeological Science: Reports, vol. 8, pp. 454-462. http:// dx.doi.org/10.1016/j.jasrep.2015.10.033.

REZENDE, R.S. 2010. Das colocações à vila: Processos de urbanização no Alto Rio Tejo, Acre. Campinas: UNICAMP, 181 p. Tese de Mestrado.

RUIZ-PÉREZ, M., ALMEIDA, M., DEWI, S., COSTA, E.M.L., PANTOJA, M.C., PUNTODEWO, A., POSTIGO, A.A. and ANDRADE, A.G., 2005. Conservation and Development in Amazonian Extractive Reserves: the case of Alto Juruá. Ambio, vol. 34, no. 3, pp. 218-223. http://dx.doi.org/10.1579/0044-7447-34.3.218. PMid:16042280.

SANTOS, R.E., PINTO-COELHO, R.M., DRUMOND, M.A., FONSECA, R. and ZANCHI, F.B., 2020. Damming Amazon Rivers: Environmental Impacts of Hydroelectric Dams on Brazil's Madeira River According to Local Fishers' Perception. Ambio, vol. 29, no. 10 , pp. 1612-1628. http://dx.doi.org/10.1007/s13280-020-01316-w. PMid:31994028.
SANTOS, R.E., PINTO-COELHO, R.M., FONSECA, R., SIMÕES, N.R. and ZANCHI, F.B., 2018. The decline of fisheries on the Madeira River, Brazil: the high cost of the hydroelectric dams in the Amazon Basin. Fisheries Management and Ecology, vol. 25, no. 5, pp. 1-12. http://dx.doi.org/10.1111/fme.12305.

SIERRA, R., 2016. Food Production Systems in the Amazon. In: SELIN $\mathrm{H}$., eds. Encyclopaedia of the history of science, technology, and medicine in non-western cultures. Dordrecht: Springer. https:// doi.org/10.1007/978-94-007-3934-5_9901-2

SILVA, A.L., \& BEGOSSI, A. 2009. Biodiversity, food consumption and ecological niche dimension: a study case of the riverine populations from the Rio Negro, Amazonia, Brazil. Environment, Development and Sustainability, vol. 11, no. 3, pp. 489-507. http:// dx.doi.org/10.1007/s10668-007-9126-z.

SILVA, J.R. and GARAVELLO, M.E., 2017. Factors influencing the food transition in riverine communities in the Brazilian Amazon. Environment, Development and Sustainability, vol. 19, no. 3, pp. 1087-1102. http://dx.doi.org/10.1007/s10668-016-9783-x.

SILVANO, R.A.M., 2020. Fish and fisheries in the Brazilian Amazon: people, ecology and conservation in black and clear water rivers. São Paulo: Springer International Publishing. . http://dx.doi. org/10.1007/978-3-030-49146-8.

SILVANO, R.A.M., DO AMARAL, B.D. and OYAKAWA, O.T., 2000. Spatial and temporal patterns of diversity and distribution of the Upper Juruá River fish community (Brazilian Amazon). Environmental Biology of Fishes, vol. 57, no. 1, pp. 25-35. http:// dx.doi.org/10.1023/A:1007594510110.

SILVANO, R.A.M., HALLWASS, G., LOPES, P.F., RIBEIRO, A.R., LIMA, R.P., HASENACK, H., JURAS, A.A. and BEGOSSI, A., 2014. Comanagement and Spatial Features Contribute to Secure Fish Abundance and Fishing Yields in Tropical Floodplain Lakes. Ecosystems (New York, N.Y.), vol. 17, no. 2, pp. 271-285. http:// dx.doi.org/10.1007/s10021-013-9722-8.

SILVANO, R.A.M., OYAKAWA, O.T., AMARAL, B.D. and BEGOSSI, A. 2001. Peixes do Alto Juruá (Amazonas, Brasil). São Paulo: EDUSP, 287 p.

SILVANO, R.A.M., RAMIRES, M. and ZUANON,J., 2009. Effects of fisheries management on fish communities in the floodplain lakes of a Brazilian Amazonian Reserve. Ecology Freshwater Fish, vol. 18, no. 1, pp. 156-166. http://dx.doi.org/10.1111/j.1600-0633.2008.00333.x.

SOBREIRO, T., FREITAS, C.E.C., PRADO, K.L., NASCIMENTO, F.A., VICENTINI, R. and MORAES, A.M., 2010. An evaluation of fishery co-management experience in an Amazonian black-water river (Unini River, Amazon, Brazil). Environment, Development and Sustainability, vol. 12, no. 6, pp. 1013-1024. http://dx.doi. org/10.1007/s10668-010-9238-8.

WINEMILLER, K.O., MCINTYRE, P.B., CASTELLO, L., FLUET-CHOUINARD, E., GIARRIZZO, T., NAM, S., BAIRD, I.G., DARWALL, W., LUJAN, N.K., HARRISON, I., STIASSNY, M.L., SILVANO, R.A., FITZGERALD, D.B., PELICICE, F.M., AGOSTINHO, A.A., GOMES, L.C., ALBERT, J.S., BARAN, E., PETRERE JUNIOR, M., ZARFL, C., MULLIGAN, M., SULLIVAN, J.P., ARANTES, C.C., SOUSA, L.M., KONING, A.A., HOEINGHAUS, D.J., SABAJ, M., LUNDBERG, J.G., ARMBRUSTER, J., THIEME, M.L., PETRY, P., ZUANON, J., TORRENTE VILARA, G., SNOEKS, J., OU, C., RAINBOTH, W., PAVANELLI, C.S., AKAMA, A., VAN SOESBERGEN, A. and SÁENZ, L., 2016. Balancing hydropower and biodiversity in the Amazon, Congo and Mekong. Science, vol. 351, no. 6269, pp. 128129. http://dx.doi.org/10.1126/science.aac7082. PMid:26744397.

ZU ERMGASSEN, E., ALCÂNTARA, M., BALMFORD, A., BARIONI, L., NETO, F., BETTARELLO, M., BRITO, G., CARRERO, G., FLORENCE, E., GARCIA, E., GONÇALVES, E., DA LUZ, C., MALLMAN, G., STRASSBURG, B., VALENTIM, J. and LATAWIEC, A., 2018. Results from On-The-Ground Efforts to Promote Sustainable Cattle Ranching in the Brazilian Amazon. Sustainability, vol. 10, no. 4, pp. 1301. http://dx.doi.org/10.3390/su10041301. 